\title{
Development of a Radiolabeled Irreversible Peptide Ligand for PET Imaging of Vascular Endothelial Growth Factor
}

\author{
Bernadette V. Marquez*1, Oluwatayo F. Ikotun*1, Jesse J. Parry², Buck E. Rogers ${ }^{2}$, Claude F. Meares ${ }^{3}$, \\ and Suzanne E. Lapi ${ }^{1}$ \\ ${ }^{1}$ Department of Radiology, Washington University School of Medicine, Saint Louis, Missouri; ${ }^{2}$ Department of Radiation Oncology, \\ Washington University School of Medicine, Saint Louis, Missouri; and ${ }^{3}$ Department of Chemistry, University of California, Davis, California
}

Imaging agents based on peptide probes have desirable pharmacokinetic properties provided that they have high affinities for their target in vivo. An approach to improve a peptide ligand's affinity for its target is to make this interaction covalent and irreversible. For this purpose, we evaluated a ${ }^{64} \mathrm{Cu}$-labeled affinity peptide tag, ${ }^{64} \mathrm{Cu}$ L19K-(5-fluoro-2,4-dinitrobenzene) ( $\left.{ }^{64} \mathrm{Cu}-\mathrm{L} 19 \mathrm{~K}-\mathrm{FDNB}\right)$, which binds covalently and irreversibly to vascular endothelial growth factor (VEGF) as a PET imaging agent. We compared the in vivo properties of ${ }^{64} \mathrm{Cu}-\mathrm{L} 19 \mathrm{~K}-\mathrm{FDNB}$ in VEGF-expressing tumor xenografts with its noncovalent binding analogs, ${ }^{64} \mathrm{Cu}$-L19K-(2,4-dinitrophenyl) $\left({ }^{64} \mathrm{Cu}-\mathrm{L} 19 \mathrm{~K}-\mathrm{DNP}\right)$ and ${ }^{64} \mathrm{Cu}-\mathrm{L} 19 \mathrm{~K}$. Methods: The L19K peptide (GGNECDIARMWEWECFERK-CONH ${ }_{2}$ ) was constructed with 1,4,7-triazacyclononane-1,4,7-triacetic acid at the $\mathrm{N}$ terminus for radiolabeling with ${ }^{64} \mathrm{Cu}$ with a polyethylene glycol spacer between peptide and chelate. 1,5-difluoro-2,4-dinitrobenzene was conjugated at the C-terminal lysine for cross-linking to VEGF, resulting in L19K-FDNB. ${ }^{64} \mathrm{Cu}-\mathrm{L} 19 \mathrm{~K}-\mathrm{FDNB}$ was assayed for covalent binding to VEGF in vitro. As a control, L19K was conjugated to 1-fluoro-2,4dinitrobenzene, resulting in L19K-DNP. PET imaging and biodistribution studies of ${ }^{64} \mathrm{Cu}-\mathrm{L} 19 \mathrm{~K}-\mathrm{FDNB},{ }^{64} \mathrm{Cu}-\mathrm{L} 19 \mathrm{~K}-\mathrm{DNP}$, and the native ${ }^{64} \mathrm{Cu}-\mathrm{L} 19 \mathrm{~K}$ were compared in HCT-116 xenografts. Blocking studies of ${ }^{64} \mathrm{Cu}-\mathrm{L} 19 \mathrm{~K}-\mathrm{FDNB}$ was performed with a coinjection of excess unlabeled L19K-FDNB. Results: In vitro binding studies confirmed the covalent and irreversible binding of ${ }^{64} \mathrm{Cu}-\mathrm{L} 19 \mathrm{~K}-\mathrm{FDNB}$ to VEGF, whereas ${ }^{64} \mathrm{Cu}-\mathrm{L} 19 \mathrm{~K}-\mathrm{DNP}$ and ${ }^{64} \mathrm{Cu}-\mathrm{L} 19 \mathrm{~K}$ did not bind covalently. PET imaging showed higher tumor uptake with ${ }^{64} \mathrm{Cu}$-L19K-FDNB than with ${ }^{64} \mathrm{Cu}-\mathrm{L} 19 \mathrm{~K}-\mathrm{DNP}$ and ${ }^{64} \mathrm{Cu}-\mathrm{L} 19 \mathrm{~K}$, with mean standardized uptake values of $0.62 \pm 0.05,0.18 \pm 0.06$, and $0.34 \pm 0.14$, respectively, at $24 \mathrm{~h}$ after injection $(P<0.05)$, and $0.53 \pm 0.05,0.32 \pm 0.14$, and $0.30 \pm 0.09$, respectively, at $48 \mathrm{~h}$ after injection $(P<0.05)$. Blocking studies with ${ }^{64} \mathrm{Cu}-\mathrm{L} 19 \mathrm{~K}$-FDNB in the presence of excess unlabeled peptide showed a $53 \%$ reduction in tumor uptake at $48 \mathrm{~h}$ after injection. Conclusion: In this proof-of-concept study, the use of a covalent binding peptide ligand against VEGF improves tracer accumulation at the tumor site in vivo, compared with its noncovalent binding peptide analogs. This technique is a promising tool to enhance the potency of peptide probes as imaging agents.

Key Words: covalent; peptide; VEGF; PET; molecular imaging

J Nucl Med 2014; 55:1029-1034

DOI: 10.2967/jnumed.113.130898

Received Aug. 26, 2013; revision accepted Jan. 24, 2014.

For correspondence contact: Suzanne E. Lapi, Department of Radiology, Washington University School of Medicine, Campus Box 8225, $510 \mathrm{~S}$. Kingshighway, Saint Louis, MO 63110.

E-mail: lapis@mir.wustl.edu

${ }^{*}$ Contributed equally to this work.

Published online Apr. 14, 2014.

COPYRIGHT (c) 2014 by the Society of Nuclear Medicine and Molecular Imaging, Inc.
C ombinatorial peptide chemistry and phage display technologies have contributed to the pool of available peptide ligands as cancer imaging constructs. Lead peptides are identified on the basis of high affinity and target selectivity in vitro and applied to the imaging modality of choice for their evaluation in vivo. Radiolabeled peptides for PET imaging are of interest because of PET's high sensitivity and quantitative properties, and the small size of peptides inherently gives them relatively fast pharmacokinetic properties. Successful examples include arginine-glycine-aspartic acid peptide analogs, which have been investigated extensively for targeting $\alpha_{\mathrm{v}} \beta_{3}$ integrin (1-3), and octreotide peptides against the somatostatin receptor $2(4,5)$. However, the development of peptide ligands with the preferred attributes of high affinity, target selectivity, high stability, and desirable pharmacokinetic properties is challenging. Most peptide ligands developed do not possess these preferred attributes and are often deemed inadequate for imaging. Approaches to prolong the residence time of peptide ligands to their targets have been used to improve affinity, stability, and pharmacokinetic properties $(2,3,6,7)$. Peptides can be modified to improve and extend the duration of target uptake by implementing covalent and permanent chemical attachment to the target, an approach that remains relatively unexplored.

Vascular endothelial growth factor (VEGF) is an important biomarker overexpressed in various cancers that stimulates endothelial cell proliferation and migration, leading to the formation of new blood vessels from preexisting ones (angiogenesis) (8). Although a secreted protein, VEGF can bind noncovalently to the extracellular matrix in the tumor vasculature, a property that allows VEGF to be targeted similarly to cell membrane-bound tumor biomarkers (9). VEGF has been successfully targeted for therapeutic and diagnostic applications, with the anti-VEGF monoclonal antibody, bevacizumab. Bevacizumab is approved by the Food and Drug Administration for antiangiogenesis treatment and has also been radiolabeled for noninvasive PET and SPECT imaging of VEGF (10-14). Radiolabeled Affibody (Affibody AB) molecules have also been investigated as VEGF imaging probes because of their nanomolar affinity for VEGF and robust structure (11).

The v107 peptide binds to VEGF with micromolar affinity, a characteristic that is generally considered as insufficiently potent for targeted molecular imaging $(15,16)$. Enhancing peptide ligand binding to its target by converting this reversible interaction with VEGF to a covalent and irreversible reaction will eliminate the peptide's dissociation from VEGF and may potentially improve target uptake. Hence, v107 was redesigned by substituting its leucine-19 residue to lysine, resulting in L19K, and was conjugated to a small library of amine-reactive cross-linkers for site-specific 


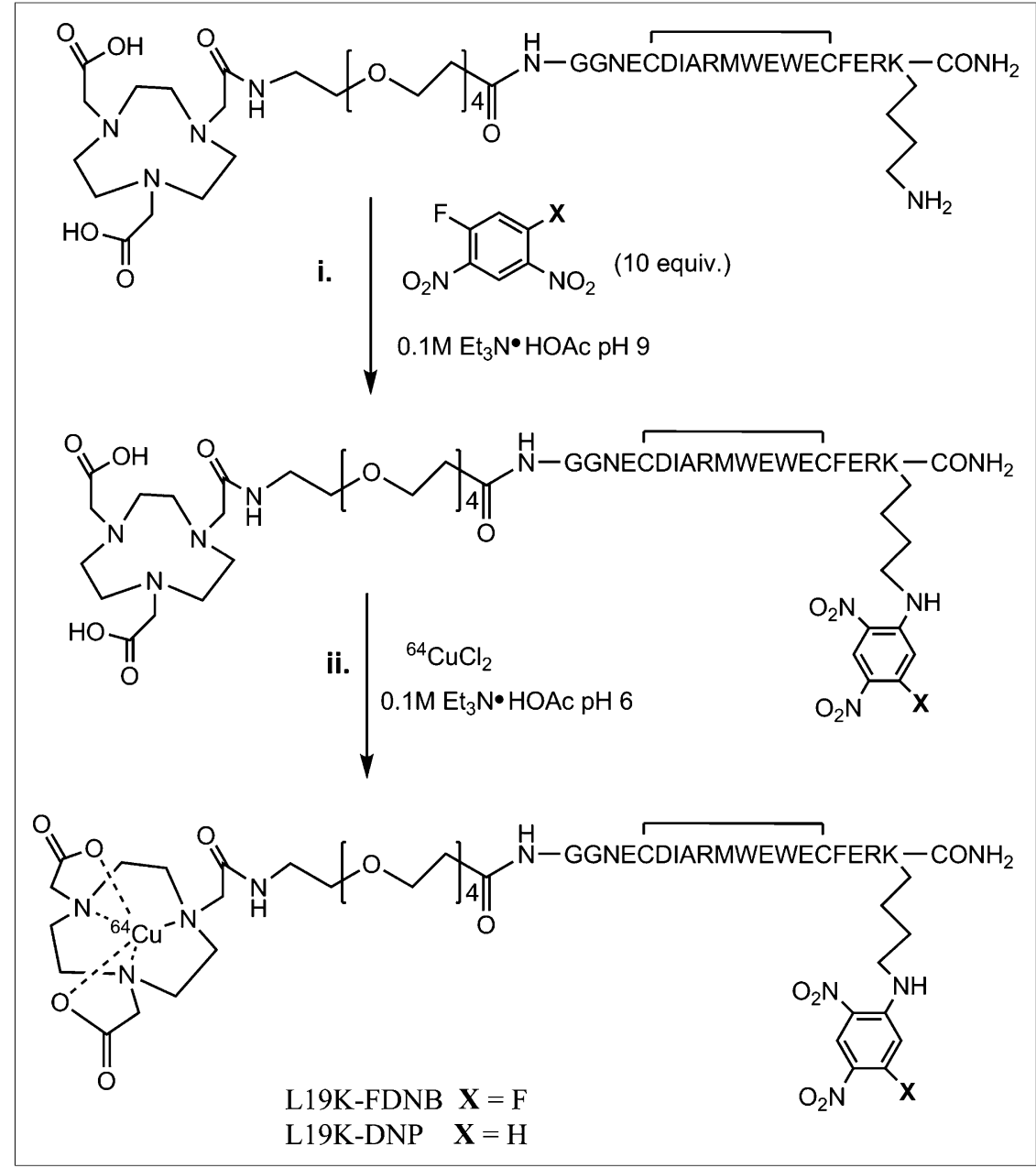

FIGURE 1. Synthesis and radiolabeling of L19K-FDNB and L19K-DNP with ${ }^{64} \mathrm{Cu}$. L19K peptide was modified with NO2A chelate at the $\mathrm{N}$ terminus and modified with fluoroaromatic linkers under basic aqueous conditions (i). After purification, peptide was radiolabeled with ${ }^{64} \mathrm{Cu}$, giving a radiochemical yield of $95 \%$ or more (ii).

covalent attachment to VEGF residue lysine-48 (17). The natural affinity of the peptide for VEGF brings the peptide's cross-linker into close proximity to VEGF lysine-48 and facilitates a covalent bond formation. The lead peptide, L19K-(5-fluoro-2,4-dinitrobenzene) (L19K-FDNB), was most reactive with VEGF, compared with other L19K conjugates in vitro (17). For the present studies, L19K-FDNB was modified to incorporate 1,4,7-triazacyclononane-1,4,7-triacetic acid (NOTA) at the peptide's $\mathrm{N}$ terminus (NO2A). We radiolabeled the peptide with ${ }^{64} \mathrm{Cu}\left({ }^{64} \mathrm{Cu}\right.$ half-life $=12.7 \mathrm{~h} ; \beta^{+}=17.8 \%, \mathrm{E}_{\max }=$ $\left.653 \mathrm{keV} ; \beta^{-}=38.4 \%, \mathrm{E}_{\max }=578 \mathrm{keV}\right)$, because ${ }^{64} \mathrm{Cu}-\mathrm{NOTA}$ complexes are stable in vitro and in vivo (18-20). We hypothesized the radiolabeled irreversible peptide agent ${ }^{64} \mathrm{Cu}-\mathrm{L} 19 \mathrm{~K}-\mathrm{FDNB}$ would improve tumor uptake, compared with its reversibly binding peptide analogs ${ }^{64} \mathrm{Cu}-\mathrm{L} 19 \mathrm{~K}-(2,4-d i n i t r o p h e n y l) \quad(64 \mathrm{Cu}-\mathrm{L} 19 \mathrm{~K}-\mathrm{DNP})$ and ${ }^{64} \mathrm{Cu}-\mathrm{L} 19 \mathrm{~K}$. Herein, we evaluate the radiolabeled irreversible peptide agent that binds covalently to VEGF as a PET imaging probe in tumor-bearing mice.

\section{MATERIALS AND METHODS}

\section{Reagents}

Chemicals and organic solvents were purchased from SigmaAldrich unless stated otherwise. Milli-Q (18 M 2 ; EMD Millipore) water was used for all buffer preparations. Cell culture reagents were purchased from Life Technologies. ${ }^{64} \mathrm{CuCl}_{2}$ was produced in house according to previous methods (21).

\section{Synthesis of L19K-FDNB and L19K-DNP}

L19K was synthesized by CPC Scientific and comprised the sequence $\mathrm{NO} 2 \mathrm{~A}-\mathrm{PEG}_{4}$ GGNECDIARMWEWECFERK-CONH${ }_{2}$, with Cys-Cys disulfide bridge and polyethylene glycol $\left(\mathrm{PEG}_{4}\right)$ as a spacer between peptide and chelator. L19K was conjugated to the 1,5-difluoro-2,4-dinitrobenzene (DFDNB), resulting in L19K-FDNB, following previous methods (17) with minor modifications. L19K (200 $\mu \mathrm{L}$ of $2 \mathrm{mM}$ solution) in $0.1 \mathrm{M}$ triethylammonium acetate $\left(\mathrm{Et}_{3} \mathrm{~N} \cdot \mathrm{HOAc}, \mathrm{pH}\right.$ 6) was prepared in an $\mathrm{HCl} / \mathrm{HNO}_{3}$ acid-washed microcentrifuge tube. Triethylamine $\left(\mathrm{Et}_{3} \mathrm{~N}\right.$, $1 \mu \mathrm{L})$ was added to $\mathrm{pH}$ approximately 10 . DFDNB dissolved in dimethyl sulfoxide (2 $\mu \mathrm{L}$ of $1 \mathrm{M}$ solution) was added to the $\mathrm{L} 19 \mathrm{~K}$ peptide and incubated at $37^{\circ} \mathrm{C}$ for $30 \mathrm{~min}$. The purification and monitoring of reaction completion followed previous methods (17). L19K-DNP was synthesized by conjugating L19K to 1-fluoro-2,4-dinitrobenzene (FDNP) as described above. The molecular weight was confirmed using electrospray ionization mass spectrometry. Peptide concentrations were estimated using a Nanodrop ultravioletvisible spectrophotometer (Thermo Scientific) at $\mathrm{A}_{350 \mathrm{~nm}}\left(\varepsilon=17,000 \mathrm{~cm}^{-1} \mathrm{M}^{-1}\right)$ for L19KFDNB and L19K-DNP (22) and at $\mathrm{A}_{280 \mathrm{~nm}}$ $\left(\varepsilon=11,500 \mathrm{~cm}^{-1} \mathrm{M}^{-1}\right)$ for unconjugated L19K at pH 6-7 (23).

\section{Radiolabeling with ${ }^{64} \mathrm{Cu}$}

${ }^{64} \mathrm{CuCl}_{2}$ was buffered in $0.1 \mathrm{M} \mathrm{Et}_{3} \mathrm{~N} \cdot \mathrm{HOAc}$, pH 6. L19K, L19K-DNP, and L19K-FDNB (5 $\mu \mathrm{g})$ buffered with 0.1 $\mathrm{M} \mathrm{Et}{ }_{3} \mathrm{~N} \cdot \mathrm{HOAc}, \mathrm{pH} 6$, was added to $18.5-37 \mathrm{MBq}(0.5-1 \mathrm{mCi})$ of ${ }^{64} \mathrm{CuCl}_{2}$ to a final concentration of $33 \mu \mathrm{M}$ peptide, and $5 \mu \mathrm{L}$ of $5 \mathrm{mM}$ ascorbic acid were added as a radioprotectant in a total volume of $50 \mu \mathrm{L}$ (24). Radiolabeling was performed at $37^{\circ} \mathrm{C}$ for $20 \mathrm{~min}$. High-performance liquid chromatography was performed to determine radiochemical purity.

\section{Small-Animal PET/CT Imaging and Biodistribution}

The institutional animal use committee approved all animal studies. Athymic $\mathrm{Nu} / \mathrm{Nu}$ mice (National Cancer Institute; age, 6-9 wk) were anesthetized with a ketamine/xylazine cocktail (VEDCO) before subcutaneous injection with $150 \mu \mathrm{L}$ of approximately $3 \times 10^{7}$ cells $/ \mathrm{mL}$ of highVEGF-expressing HCT-116 or low-VEGF-expressing SSTR2-SKOV3 suspended in saline. Tumors were allowed to grow $40-200 \mathrm{~mm}^{3}$ for 1-2 wk.

HCT-116 tumor-bearing mice were injected with $100 \mu \mathrm{L}$ of 7.4 $\mathrm{MBq}(200 \mu \mathrm{Ci})$ of ${ }^{64} \mathrm{Cu}-\mathrm{L} 19 \mathrm{~K}-\mathrm{FDNB},{ }^{64} \mathrm{Cu}-\mathrm{L} 19 \mathrm{~K}-\mathrm{DNP}$, or ${ }^{64} \mathrm{Cu}-$ L19K via the tail vein. Mice were sacrificed at $24 \mathrm{~h}(n=3-5), 48 \mathrm{~h}$ $(n=3)$, and $72 \mathrm{~h}(n=3)$ after injection for biodistribution studies, and the 48-h subset of mice was imaged by PET/CT at 24 and $48 \mathrm{~h}$ after injection. Unlabeled L19K-FDNB $(138 \mu \mathrm{g})$ was coinjected with $1.8 \mu \mathrm{g}$ of ${ }^{64} \mathrm{Cu}-\mathrm{L} 19 \mathrm{~K}-\mathrm{FDNB}(7.4 \mathrm{MBq}, n=3)$ in saline for a total volume of $200 \mu \mathrm{L}$ for blocking studies at $48 \mathrm{~h}$ after injection. The 


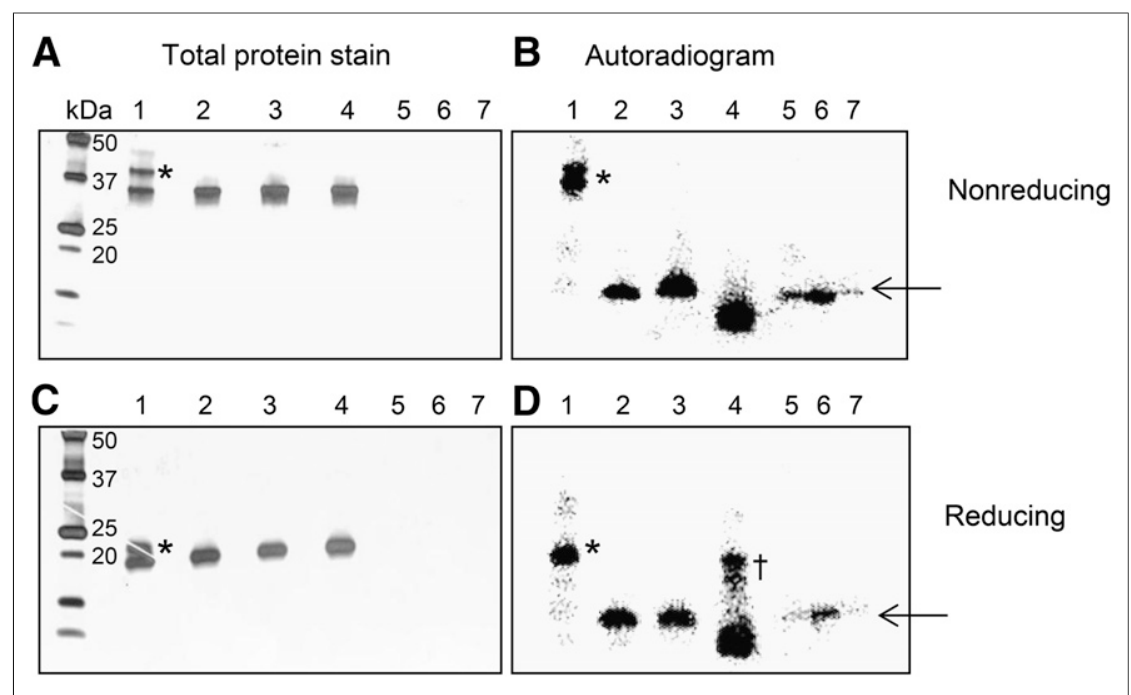

FIGURE 2. Autoradiographic SDS-PAGE analysis of VEGF binding study in vitro. Soluble human VEGF (2 equivalents) was reacted with ${ }^{64} \mathrm{Cu}$-L19K-FDNB (lane 1), ${ }^{64} \mathrm{Cu}-\mathrm{L} 19 \mathrm{~K}-\mathrm{DNP}$ (lane 2), ${ }^{64} \mathrm{Cu}$ L19K (lane 3), or ${ }^{64} \mathrm{Cu}-\mathrm{EDTA}$ (lane 4). Controls with only peptides are ${ }^{64} \mathrm{Cu}-\mathrm{L} 19 \mathrm{~K}-\mathrm{FDNB}$ (lane 5), ${ }^{64} \mathrm{Cu}-\mathrm{L} 19 \mathrm{~K}-\mathrm{DNP}$ (lane 6), and ${ }^{64} \mathrm{Cu}-\mathrm{L} 19 \mathrm{~K}$ (lane 7). Denaturing conditions were applied to each reaction under nonreducing $(A$ and $B)$ and reducing $(C$ and $D)$ conditions. Gels were imaged by autoradiography (B and $\mathrm{D}$ ) and stained for total protein ( $\mathrm{A}$ and $\mathrm{C}) .{ }^{*}$ marks band corresponding to ${ }^{64} \mathrm{Cu}$-L19K-FDNB-VEGF covalent product. Arrows indicate migration of unreacted peptides, only detectable with autoradiography. Under reducing conditions, VEGF is reduced to its monomer form. $†$ shows transchelated ${ }^{64} \mathrm{Cu}$ to free cysteine residues on reduced VEGF monomer from control reaction between VEGF and ${ }^{64} \mathrm{Cu}$-EDTA (D lane 4). This transchelation is not observed in ${ }^{64} \mathrm{Cu}-\mathrm{NO} 2 \mathrm{~A}$-peptide reactions (D lanes $1-3$ ). EDTA = ethylenediamine tetraacetic acid; SDSPAGE $=$ sodium dodecyl sulfate-polyacrylamide gel electrophoresis

preliminary pharmacokinetic studies of ${ }^{64} \mathrm{Cu}-\mathrm{L} 19 \mathrm{~K}-\mathrm{FDNB}$ were investigated in both HCT-116 and SSTR2-SKOV3 xenografts.

Details about additional methods are provided in the supplemental materials (available at http://jnm.snmjournals.org).

\section{RESULTS}

\section{Peptide Characterization, Radiolabeling, and Stability}

The conjugation of L19K to either DFDNB or FDNP linkers (Fig. 1) resulted in quantitative conversion of L19K to L19KFDNB or L19K-DNP, respectively, characterized by mass spectrometry (Supplemental Figs. 1 and 2). Subsequent radiolabeling of L19K-FDNB, L19K-DNP, and the native $\mathrm{L} 19 \mathrm{~K}$ with ${ }^{64} \mathrm{Cu}$ each gave a $95 \%$ or more radiochemical yield, with retention times of 17.7, 17.6, and $13.1 \mathrm{~min}$, respectively (Supplemental Figs. 3-5). The specific activity was $11.1 \mathrm{GBq} / \mu \mathrm{mol}$. The radiolabeled peptides were used for in vitro and in vivo studies without further purification.

In vitro serum stability studies of ${ }^{64} \mathrm{Cu}-\mathrm{L} 19 \mathrm{~K},{ }^{64} \mathrm{Cu}-\mathrm{L} 19 \mathrm{~K}-\mathrm{DNP}$, and ${ }^{64} \mathrm{Cu}-\mathrm{L} 19 \mathrm{~K}-\mathrm{FDNB}$ were performed in a 1:1 phosphate-buffered saline:fetal bovine serum solution ( $\mathrm{pH} \mathrm{7.4)}$ at $37^{\circ} \mathrm{C}$ for up to $24 \mathrm{~h}$. All peptides showed no ${ }^{64} \mathrm{Cu}$ decomplexation and minimal peptide degradation up to $24 \mathrm{~h}$ (Supplemental Figs. 6-8). Some nonspecific binding of ${ }^{64} \mathrm{Cu}-\mathrm{L} 19 \mathrm{~K}-\mathrm{FDNB}$ to serum proteins was observed at $24 \mathrm{~h}$ (Supplemental Fig. 8). Further stability studies with ${ }^{64} \mathrm{Cu}-$ L19K-FDNB spiked with excess unlabeled L19K-FDNB in phosphatebuffered saline ( $\mathrm{pH}$ 7.4) to monitor the fluoroaromatic cross-linker at $\mathrm{A}_{350 \mathrm{~nm}}$ resulted in a relatively stable product with minimal hydrolysis at $24 \mathrm{~h}$ (Supplemental Fig. 9).

\section{In Vitro Binding Studies}

${ }^{64} \mathrm{Cu}-\mathrm{L} 19 \mathrm{~K}-\mathrm{FDNB},{ }^{64} \mathrm{Cu}-\mathrm{L} 19 \mathrm{~K}-\mathrm{DNP}$, and ${ }^{64} \mathrm{Cu}-\mathrm{L} 19 \mathrm{~K}$ were bound to 2-fold equivalents of soluble VEGF in a phosphate-buffered solution, and these reactions were subsequently analyzed via autoradiographic sodium dodecyl sulfate-polyacrylamide gel electrophoresis analysis under denaturing conditions in the absence (nonreducing) and presence of a thiol-containing reducing agent (reducing). Under nonreducing conditions, the total protein stain showed bands for noncovalently bound VEGF migrating between 25 and $37 \mathrm{kDa}$, whereas covalently bound VEGF migrated between 37 and $50 \mathrm{kDa}$ (Fig. 2A). Although total protein stain does not detect the peptides at the concentration used, the autoradiogram of the same gel confirms the migration pattern of each ${ }^{64} \mathrm{Cu}$-labeled peptide (Fig. 2B). Only ${ }^{64} \mathrm{Cu}-\mathrm{L} 19 \mathrm{~K}-\mathrm{FDNB}$ completely reacted covalently to VEGF, migrating between 37 and $50 \mathrm{kDa}$ (Fig. 2B, lane 1), and the corresponding total protein stain showed 2 bands of about equal intensity associated with unreacted VEGF migrating between 25 and $37 \mathrm{kDa}$ and covalently reacted VEGF migrating between 37 and $50 \mathrm{kDa}$ (Fig. 2A, lane 1). An attempt to reverse this nucleophilic aromatic substitution product with a $\beta$-mercaptoethanol-reducing agent did not displace ${ }^{64} \mathrm{Cu}-\mathrm{L} 19 \mathrm{~K}-\mathrm{FDNB}$ from the VEGF monomer, migrating between 20 and $25 \mathrm{kDa}$ (Figs. $2 \mathrm{C}$ and $2 \mathrm{D}) .{ }^{64} \mathrm{Cu}-$ L19K-DNP and ${ }^{64} \mathrm{Cu}-\mathrm{L} 19 \mathrm{~K}$ did not bind covalently to VEGF, indicated by the absence of this band between 20 and $25 \mathrm{kDa}$ and the presence of unreacted ${ }^{64} \mathrm{Cu}-\mathrm{L} 19 \mathrm{~K}-\mathrm{DNP}$ and ${ }^{64} \mathrm{Cu}-\mathrm{L} 19 \mathrm{~K}$ at the bottom of the gel (Fig. 2, lanes 2 and 3). Under reducing conditions, VEGF unlocks its disulfide bonds to release free sulfhydryl groups, which transchelated some ${ }^{64} \mathrm{Cu}$ in the control reaction (Fig. 2D, lane 4); however, this transchelation was not observed in the ${ }^{64} \mathrm{Cu}-\mathrm{NO} 2 \mathrm{~A}-$ peptide reactions (Fig. 2D, lanes 1-3). The reactivity of ${ }^{64} \mathrm{Cu}-\mathrm{L} 19 \mathrm{~K}-$ FDNB was further examined with mouse VEGF, because our in vivo models express endogenous mouse VEGF. As expected, ${ }^{64} \mathrm{Cu}-$ L19K-FDNB also covalently bound to mouse VEGF because of the conserved epitope recognized by the peptide in both homologs (Supplemental Fig. 10) (16,17,25).

Cellular binding studies were performed to investigate the specificity of ${ }^{64} \mathrm{Cu}-\mathrm{L} 19 \mathrm{~K}-\mathrm{FDNB}$ using VEGF-expressing HCT116 cells. The cellular uptake of $17.8 \% \pm 9.06 \%$ was observed with significant reduction to $1.75 \% \pm 0.51 \%(P<0.05)$ when pretreated with unlabeled L19K-FDNB and $0.56 \% \pm 0.24 \%(P<$ 0.05) with bevacizumab (Fig. 3). Cellular uptake comparing the blocking conditions using unlabeled L19K-FDNB and bevacizumab were not significant $(P>0.05)$.

\section{In Vivo Small-Animal PET Imaging and Biodistribution}

We first evaluated the pharmacokinetic properties of ${ }^{64} \mathrm{Cu}$ L19K-FDNB in tumor-bearing mice with varying levels of VEGF expression at 2, 24, and $48 \mathrm{~h}$ after injection. The expression of somatostatin receptor 2 (SSTR2) is reported to downregulate VEGF expression $(26,27)$, thus a transfected cell line, SSTR2SKOV3, was used as a low-level human VEGF model. The validation of SSTR2 transfection in the SSTR2-SKOV3 cells was performed via flow cytometry and shows positive expression of 


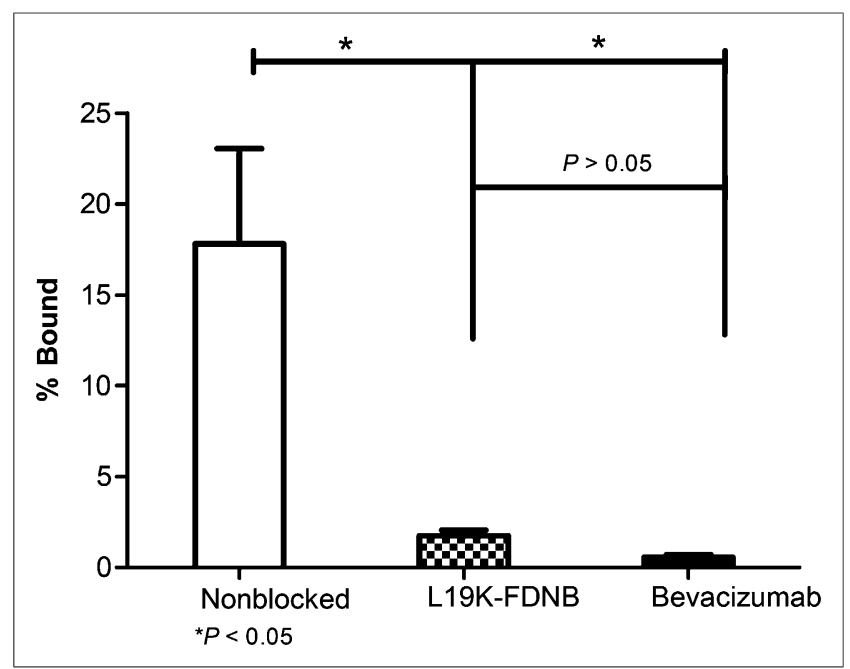

FIGURE 3. Cell-binding studies of ${ }^{64} \mathrm{Cu}-\mathrm{L} 19 \mathrm{~K}-\mathrm{FDNB}$ to VEGFexpressing HCT-116 show specific binding by reduction of uptake in presence of pretreated unlabeled L19K-FDNB or bevacizumab.

SSTR2 (Supplemental Fig. 11). Human VEGF expression levels in the 2 cell lines were determined via Western blotting, confirming higher VEGF expression with HCT-116 than SSTR2-SKOV3 (Supplemental Fig. 12). Biodistribution studies for ${ }^{64} \mathrm{Cu}-\mathrm{L} 19 \mathrm{~K}-\mathrm{FDNB}$ at $2 \mathrm{~h}$ after injection yielded similar tumor uptake $(P>0.05)$ between HCT-116 and SSTR2-SKOV3 xenografts, suggesting passive uptake. At $24 \mathrm{~h}$, higher tumor-associated radioactivity was observed in HCT116 than in SSTR2-SKOV3 tumor xenografts, with $3.36 \pm 0.33$ $(n=5)$ and $1.76 \pm 0.60$ percentage injected dose per gram $(\% \mathrm{ID} / \mathrm{g})$ ( $n=5, P<0.01$ ), respectively (Supplemental Fig. 13). This difference was also significant at $48 \mathrm{~h}(P<0.01)$ (Supplemental Fig. 13). Blood clearance was similar in both xenograft models, in which blood residency decreased by 2 -fold after each time point (Supplemental Fig. 13). High kidney uptake was initially observed in both models: $32.42 \pm 7.71 \% \mathrm{ID} / \mathrm{g}$ at $2 \mathrm{~h}$, decreasing to $5.65 \pm 0.69$, and $3.83 \% \pm 0.56 \% \% \mathrm{ID} / \mathrm{g}$ at 24 and $48 \mathrm{~h}$, respectively, in HCT-116 mice (Supplemental Fig. 13). The similar biodistribution of ${ }^{64} \mathrm{Cu}-$ L19K-FDNB in nontarget organs of both models is indicative of

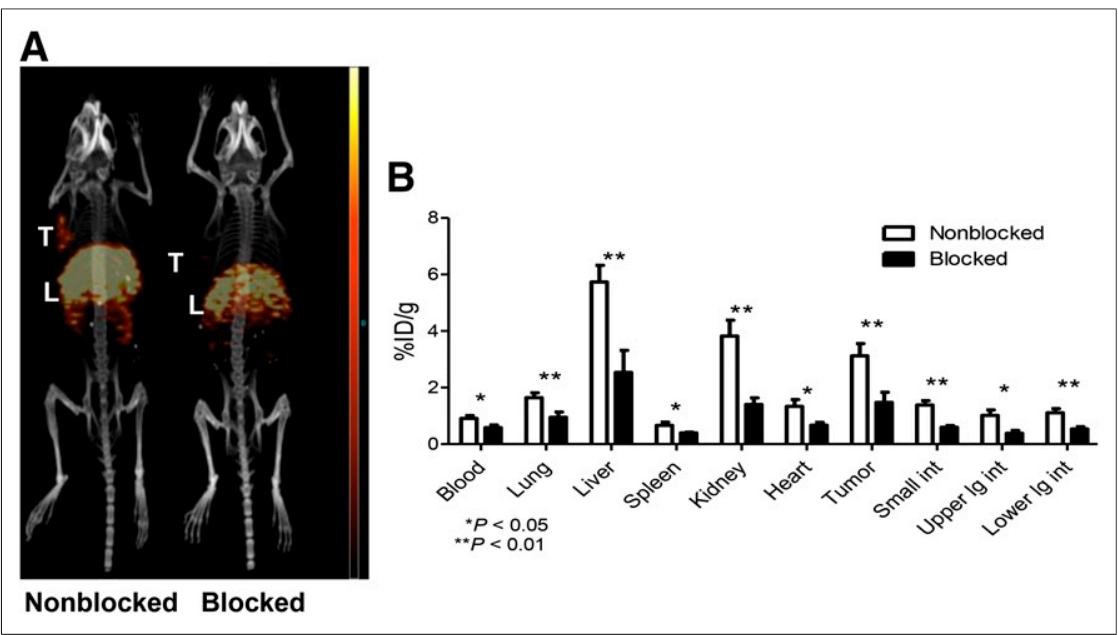

FIGURE 4. Blocking of ${ }^{64} \mathrm{Cu}-\mathrm{L} 19 \mathrm{~K}-F D N B$ with excess unlabeled L19K-FDNB in HCT-116 xenografts, $48 \mathrm{~h}$ after injection. PET image shows reduced uptake in tumor and liver (A), which is corroborated by biodistribution studies $(B)$. binding to endogenous mouse VEGF. These results suggest that optimal imaging can be achieved at later time points, for which higher tumor uptake in the high-VEGF-expressing tumor and a decrease in renal- and bloodstream-associated radioactivity were achieved. Thus, successive imaging studies were conducted starting from $24 \mathrm{~h}$ after injection.

Blocking studies were performed to evaluate the in vivo specificity of ${ }^{64} \mathrm{Cu}-\mathrm{L} 19 \mathrm{~K}-\mathrm{FDNB}$ by coinjection with $138 \mu \mathrm{g}$ of unlabeled L19K-FDNB. PET imaging studies showed a significant decrease in tracer tumor uptake in the presence of excess unlabeled L19K-FDNB (Fig. 4A). Biodistribution studies corroborate $\mathrm{PET}$ imaging studies, in which a $53 \%$ reduction ${ }^{64} \mathrm{Cu}-\mathrm{L} 19 \mathrm{~K}-$ FDNB tumor binding was observed, decreasing from $3.12 \pm 0.43$ to $1.48 \pm 0.36 \% \mathrm{ID} / \mathrm{g}(n=3, P=0.008)$ (Fig. $4 \mathrm{~B})$. In addition to the tumor, liver and kidney uptake were also reduced in the presence of unlabeled L19K-FDNB. Liver uptake was reduced by $56 \%$ from $5.73 \pm 0.59$ to $2.53 \pm 0.78 \% \mathrm{ID} / \mathrm{g}(n=3, P=0.006)$, and kidney uptake was reduced by $63 \%$ from $3.83 \pm 0.56$ to $1.41 \pm$ $0.23 \% \mathrm{ID} / \mathrm{g}$ under nonblocking and blocking conditions, respectively ( $n=3, P=0.009$ ) (Fig. 4C). These results suggest that ${ }^{64} \mathrm{Cu}-\mathrm{L} 19 \mathrm{~K}-\mathrm{FDNB}$ is selective for VEGF, and blocking in normal organs may be attributed to endogenously expressed VEGF $(28,29)$

\section{Comparison of ${ }^{64} \mathrm{Cu}-\mathrm{L} 19 \mathrm{~K}-\mathrm{FDNB},{ }^{64} \mathrm{Cu}-\mathrm{L} 19 \mathrm{~K}-\mathrm{DNP}$, and ${ }^{64} \mathrm{Cu}-\mathrm{L} 19 \mathrm{~K}$}

${ }^{64} \mathrm{Cu}$-labeled L19K-FDNB, L19K-DNP, and L19K were evaluated by PET imaging at 24 and $48 \mathrm{~h}$ after injection and by biodistribution studies at 24,48 , and $72 \mathrm{~h}$ in HCT-116 xenografts. Quantitative region-of-interest analysis of PET images revealed that ${ }^{64} \mathrm{Cu}-\mathrm{L} 19 \mathrm{~K}-\mathrm{FDNB}$ has the highest tumor uptake, compared with the lipophilic ${ }^{64} \mathrm{Cu}-\mathrm{L} 19 \mathrm{~K}-\mathrm{DNP}$ and the native ${ }^{64} \mathrm{Cu}-\mathrm{L} 19 \mathrm{~K}$, with a mean standardized uptake value (SUV) of $0.62 \pm 0.05$, $0.18 \pm 0.06$, and $0.34 \pm 0.14$, respectively, at $24 \mathrm{~h}$ after injection and $0.53 \pm 0.05,0.32 \pm 0.14$, and $0.30 \pm 0.09$, respectively, at $48 \mathrm{~h}$ after injection (Fig. 5). Statistical analysis determined significant differences $(P<0.05)$ between ${ }^{64} \mathrm{Cu}-\mathrm{L} 19 \mathrm{~K}-\mathrm{FDNB}$ and each control peptide at both 24 and $48 \mathrm{~h}$ after injection. Differences between ${ }^{64} \mathrm{Cu}-\mathrm{L} 19 \mathrm{~K}-\mathrm{DNP}$ and the native ${ }^{64} \mathrm{Cu}-\mathrm{L} 19 \mathrm{~K}$ were not significant at either time point $(P>0.05)$. Biodistribution values follow the same trend as SUV; however, the intertumoral variability and small sample size in these terminal studies does not provide statistical power to be significant at individual time points. At $24 \mathrm{~h}$, the tumor uptake values were $3.94 \pm 0.98,2.43 \pm$ 0.55 , and $2.83 \pm 0.80 \% \mathrm{ID} / \mathrm{g}$ for ${ }^{64} \mathrm{Cu}-$ L19K-FDNB, ${ }^{64} \mathrm{Cu}-\mathrm{L} 19 \mathrm{~K}-\mathrm{DNP}$, and ${ }^{64} \mathrm{Cu}-$ L19K, respectively (Supplemental Table 1). At this time point, only the difference between ${ }^{64} \mathrm{Cu}-\mathrm{L} 19 \mathrm{~K}-\mathrm{FDNB}$ and ${ }^{64} \mathrm{Cu}-$ L19K-DNP was significant $(P=0.004)$, but the difference between ${ }^{64} \mathrm{Cu}-\mathrm{L} 19 \mathrm{~K}$ FDNB and ${ }^{64} \mathrm{Cu}-\mathrm{L} 19 \mathrm{~K}$ was not significant $(P>0.05)$. Also, the difference between ${ }^{64} \mathrm{Cu}-\mathrm{L} 19 \mathrm{~K}-\mathrm{DNP}$ and ${ }^{64} \mathrm{Cu}-\mathrm{L} 19 \mathrm{~K}$ was not significant $(P>0.05)$. Furthermore, statistical analyses for the 48- and 72-h data did not yield significant differences among the peptides at each of these time points (Supplemental Tables 2 and 3). However, 


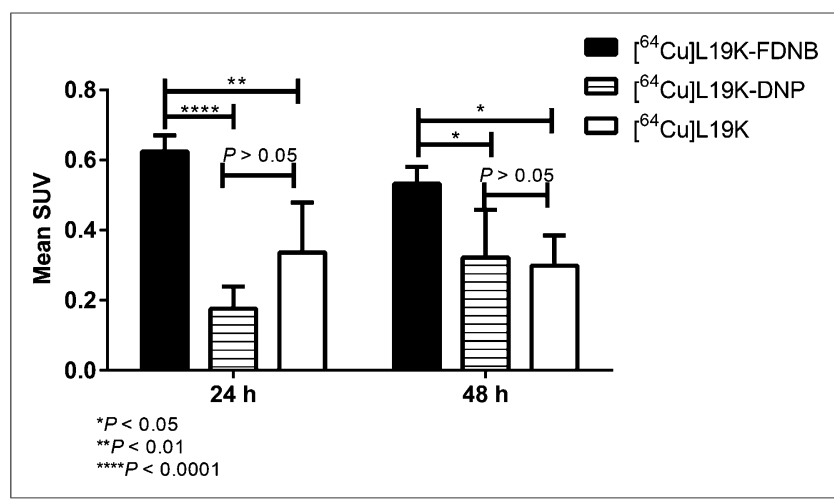

FIGURE 5. Tumor uptake comparison of ${ }^{64} \mathrm{Cu}-\mathrm{L} 19 \mathrm{~K}-\mathrm{FDNB},{ }^{64} \mathrm{Cu}-$ L19K-DNP, and ${ }^{64} \mathrm{Cu}-\mathrm{L} 19 \mathrm{~K}$ in HCT-116 xenografts.

the collective effect of ${ }^{64} \mathrm{Cu}-\mathrm{L} 19 \mathrm{~K}-\mathrm{FDNB}$ at all time points $(n=9)$ gave enough statistical power to be significantly different from ${ }^{64} \mathrm{Cu}-\mathrm{L} 19 \mathrm{~K}-\mathrm{DNP}(n=12, P=0.0092)$ and ${ }^{64} \mathrm{Cu}-\mathrm{L} 19 \mathrm{~K}(n=9$, $P=0.025)$, whereas the difference between ${ }^{64} \mathrm{Cu}-\mathrm{L} 19 \mathrm{~K}-\mathrm{DNP}$ and ${ }^{64} \mathrm{Cu}-\mathrm{L} 19 \mathrm{~K}$ was not significant $(P>0.999)$. Thus, the tumor uptake of the covalent binding ${ }^{64} \mathrm{Cu}-\mathrm{L} 19 \mathrm{~K}-\mathrm{FDNB}$ surpasses those of its noncovalent analogs, ${ }^{64} \mathrm{Cu}-\mathrm{L} 19 \mathrm{~K}-\mathrm{DNP}$ and ${ }^{64} \mathrm{Cu}-\mathrm{L} 19 \mathrm{~K}$.

\section{DISCUSSION}

We evaluated a radiolabeled irreversible peptide agent, ${ }^{64} \mathrm{Cu}-$ L19K-FDNB, as a PET imaging probe for VEGF in tumor-bearing mice. In diagnostic imaging, affinity-enhanced covalent binding of peptide probes has thus far been applied only to pretargeting methods involving the covalent binding of a radiolabeled peptide to an engineered targeting vector rather than directly to a natural biomarker (30). Other affinity-enhanced covalent binding imaging agents based on small ligands have also been investigated in artificial receptors in vivo, yielding excellent imaging contrast because of the probe's fast pharmacokinetic properties and improved affinity for its target $(31,32)$. Exploring this concept to target a natural biomarker using a peptide ligand is relatively uncharted. As proof of concept, we applied the previously developed L19K-FDNB ligand that binds covalently and irreversibly to VEGF as a PET imaging agent, to improve the potency of low-affinity peptide probes $(14,15)$.

Substituting ${ }^{64} \mathrm{Cu}-\mathrm{NO} 2 \mathrm{~A}$ as the detection moiety at the peptide's $\mathrm{N}$ terminus did not affect the cross-linking reaction of L19KFDNB to VEGF. This strategy requires the noncovalent binding equilibrium between peptide and VEGF to bring the peptide's cross-linker into close proximity to VEGF Lys-48 to facilitate a nucleophilic aromatic substitution reaction, while remaining unreactive to other nucleophilic amino acid side chain groups (Fig. 6) (17).

Exemplified by in vivo pharmacokinetic studies, ${ }^{64} \mathrm{Cu}-\mathrm{L} 19 \mathrm{~K}-$ FDNB is capable of differentiating varying VEGF expression levels between HCT-116 and SSTR2-SKOV3 tumor xenografts at $24 \mathrm{~h}(P<0.01)$ and $48 \mathrm{~h}(P<0.01)$ after injection. Additionally, background in normal tissues requires several hours to resolve so we focused on imaging at later times. Other factors such as different tumor vascularization or irregular tumor growth may also affect the biodistribution of ${ }^{64} \mathrm{Cu}-\mathrm{L} 19 \mathrm{~K}-\mathrm{FDNB}$ other than VEGF expression levels, and more studies are needed to analyze these physiologic differences. However, we have shown in vivo specificity for VEGF in our blocking studies, in which a $53 \%$ reduction in tumor-associated activity was observed in the presence of excess unlabeled peptide $(P=0.008)$ in the HCT-116 xenografts
(Fig. 4). Other organs expressing endogenous VEGF such as the liver, kidneys, and blood were also significantly blocked $(P<$ 0.05). This cross-reactivity of ${ }^{64} \mathrm{Cu}-\mathrm{L} 19 \mathrm{~K}-\mathrm{FDNB}$ to mouse VEGF, also verified in vitro (Supplemental Fig. 10), predicts a more relevant biodistribution for clinical purposes.

Because the incorporation of the fluoroaromatic cross-linker changes the lipophilicity of the peptide, we compared ${ }^{64} \mathrm{Cu}-\mathrm{L} 19 \mathrm{~K}-$ FDNB with a similar but unreactive peptide conjugate, ${ }^{64} \mathrm{Cu}-\mathrm{L} 19 \mathrm{~K}-$ DNP, serving as a lipophilic peptide control. High-performance liquid chromatography analysis of ${ }^{64} \mathrm{Cu}-\mathrm{L} 19 \mathrm{~K}-\mathrm{DNP}$ shows a retention time similar to ${ }^{64} \mathrm{Cu}-\mathrm{L} 19 \mathrm{~K}-\mathrm{FDNB}$ at 17.6 and $17.7 \mathrm{~min}$, respectively. In vitro binding studies show that ${ }^{64} \mathrm{Cu}-\mathrm{L} 19 \mathrm{~K}-\mathrm{FDNB}$ binds covalently and irreversibly to VEGF, whereas ${ }^{64} \mathrm{Cu}-\mathrm{L} 19 \mathrm{~K}-\mathrm{DNP}$ and the native ${ }^{64} \mathrm{Cu}-\mathrm{L} 19 \mathrm{~K}$ do not bind covalently (Fig. 2). Although it is difficult to prove covalent binding in vivo, results from in vitro binding studies and the structural similarity between the ${ }^{64} \mathrm{Cu}-\mathrm{L} 19 \mathrm{~K}-\mathrm{FDNB}$ and ${ }^{64} \mathrm{Cu}-\mathrm{L} 19 \mathrm{~K}$-DNP suggest that any differences between these probes in vivo are more likely due to covalent binding of ${ }^{64} \mathrm{Cu}-$ L19K-FDNB. Comparative studies between these peptide conjugates along with the native ${ }^{64} \mathrm{Cu}-\mathrm{L} 19 \mathrm{~K}$ in vivo showed highest tumor uptake with ${ }^{64} \mathrm{Cu}-\mathrm{L} 19 \mathrm{~K}-\mathrm{FDNB}$ at 24 and $48 \mathrm{~h}$ after injection $(P<0.05)$, as determined by PET imaging using SUV analysis (Fig. 5). Biodistribution studies support SUV analysis with the same trend at 24 and $48 \mathrm{~h}$; however, a larger sample population size is necessary at the individual time points to achieve statistical power. These terminal studies contribute a larger intertumoral variability, especially when the sample size is small. PET imaging studies follow

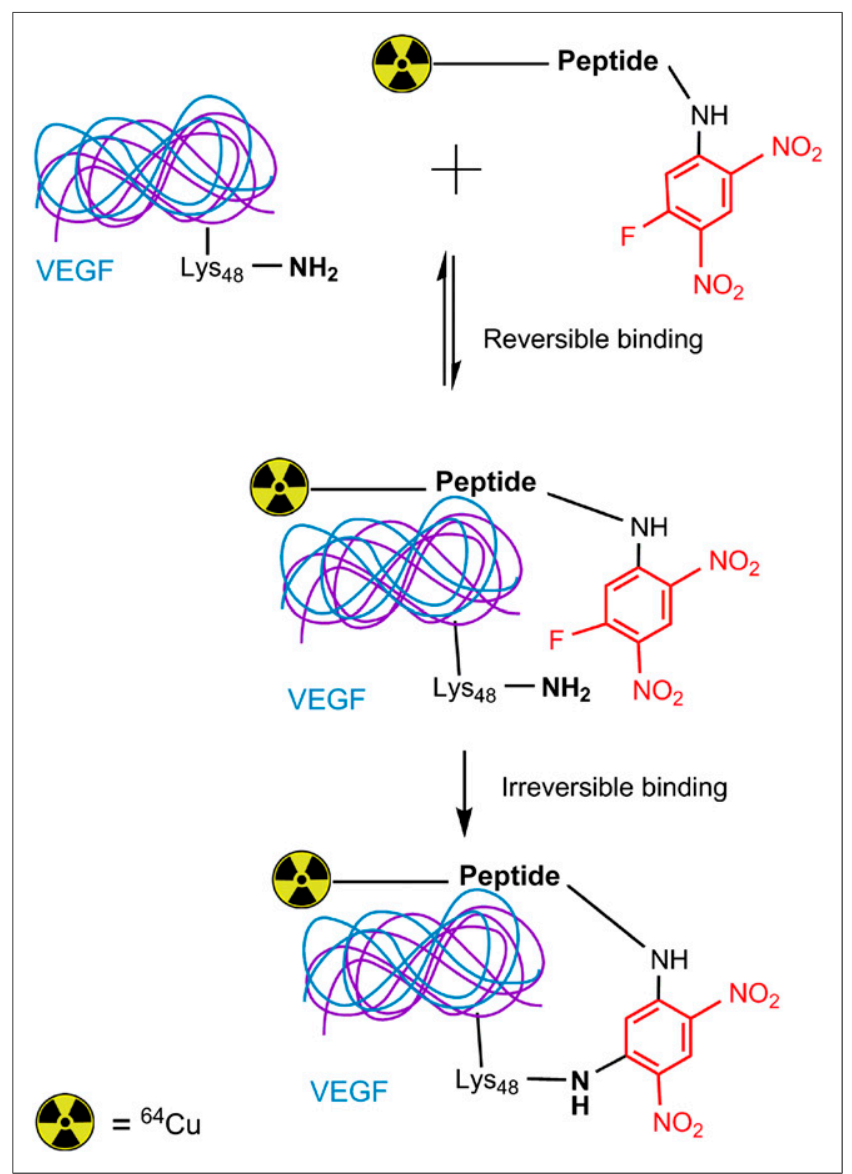

FIGURE 6. Proposed mechanism for affinity-enhanced site-specific covalent binding of ${ }^{64} \mathrm{Cu}-\mathrm{L} 19 \mathrm{~K}-\mathrm{FDNB}$ to VEGF, adapted from Marquez et al. (17). 
the same subset of mice at the different time points so that the variability between mice over time are reduced. Two-way ANOVA analysis determined the biodistribution studies at 24,48 , and $72 \mathrm{~h}$ after injection collectively confirm the tumor uptake of ${ }^{64} \mathrm{Cu}-\mathrm{L} 19 \mathrm{~K}-\mathrm{FDNB}$ is significantly higher than ${ }^{64} \mathrm{Cu}-\mathrm{L} 19 \mathrm{~K}-\mathrm{DNP}(P=0.009)$ or ${ }^{64} \mathrm{Cu}-\mathrm{L} 19 \mathrm{~K}$ $(P=0.025)$, the difference between ${ }^{64} \mathrm{Cu}-\mathrm{L} 19 \mathrm{~K}-\mathrm{DNP}$ and ${ }^{64} \mathrm{Cu}-\mathrm{L} 19 \mathrm{~K}$ was not significant $(P>0.999)$. Thus, the lipophilicity contributed by the cross-linkers in ${ }^{64} \mathrm{Cu}-\mathrm{L} 19 \mathrm{~K}-\mathrm{FDNB}$ and ${ }^{64} \mathrm{Cu}-\mathrm{L} 19 \mathrm{~K}-\mathrm{DNP}$ does not appear to improve tumor uptake, and the improved tumor uptake is consistent with the covalent binding ${ }^{64} \mathrm{Cu}-\mathrm{L} 19 \mathrm{~K}-\mathrm{FDNB}$. Overall, our results indicate that the enhancement of peptide ligand binding via irreversible binding is a promising tool to advance low-affinity peptides as molecular imaging agents and improve tumor accumulation.

\section{CONCLUSION}

${ }^{64} \mathrm{Cu}-\mathrm{L} 19 \mathrm{~K}-\mathrm{FDNB}$ enhances tumor uptake, compared with the noncovalent binding ${ }^{64} \mathrm{Cu}-\mathrm{L} 19 \mathrm{~K}-\mathrm{DNP}$ and ${ }^{64} \mathrm{Cu}-\mathrm{L} 19 \mathrm{~K}$, in vivo. Covalent binding peptides offer a means to improve the performance of low-affinity peptides in vivo and warrant further investigations in other peptide-target systems.

\section{DISCLOSURE}

The costs of publication of this article were defrayed in part by the payment of page charges. Therefore, and solely to indicate this fact, this article is hereby marked "advertisement" in accordance with 18 USC section 1734. We thank the Alvin J. Siteman Cancer Center at Washington University School of Medicine and BarnesJewish Hospital for the use of the Proteomics Core, which provided mass spectrometry service, supported in part by NCI Cancer Center support grant \#P30 CA91842. This work was supported by the Department of Energy under grant DESC0002032. No other potential conflict of interest relevant to this article was reported.

\section{ACKNOWLEDGMENTS}

We thank the Washington University Small Animal Imaging Facility for PET and biodistribution studies, the Washington University isotope production team for production of ${ }^{64} \mathrm{Cu}$, Alex Zheleznyak for helpful discussions, and Tim Whitehead for statistics consult. This paper was presented in part at the 20th International Symposium on Radiopharmaceutical Sciences 2013 in Jeju, Korea; at the Korean Chemical Society KCS-ACR Symposium 2013 in Seoul, Korea; and at the Monoclonal Antibodies in Medicine Symposium 2013 in Mykonos, Greece.

\section{REFERENCES}

1. Temming K, Schiffelers RM, Molema G, Kok RJ. RGD-based strategies for selective delivery of therapeutics and imaging agents to the tumour vasculature. Drug Resist Updat. 2005;8:381-402.

2. Jacobson O, Zhu L, Niu G, et al. MicroPET imaging of integrin $\alpha_{\mathrm{v}} \beta_{3}$ expressing tumors using ${ }^{89} \mathrm{Zr}$-RGD peptides. Mol Imaging Biol. 2011;13:1224-1233.

3. Shi J, Kim YS, Zhai S, Liu Z, Chen X, Liu S. Improving tumor uptake and pharmacokinetics of ${ }^{64} \mathrm{Cu}$-labeled cyclic RGD peptide dimers with Gly(3) and PEG(4) linkers. Bioconjug Chem. 2009;20:750-759.

4. Velikyan I, Sundin A, Eriksson B, et al. In vivo binding of $\left[{ }^{68} \mathrm{Ga}\right]$-DOTATOC to somatostatin receptors in neuroendocrine tumours: impact of peptide mass. Nucl Med Biol. 2010;37:265-275.

5. Pruszyński M, Majkowska-Pilip A, Loktionova NS, Eppard E, Roesch F. Radiolabeling of DOTATOC with the long-lived positron emitter ${ }^{44} \mathrm{Sc}$. Appl Radiat Isot. 2012;70:974-979.
6. Koehler MFT, Zobel K, Beresini MH, et al. Albumin affinity tags increase peptide half-life in vivo. Bioorg Med Chem Lett. 2002;12:2883-2886.

7. Aina OH, Liu R, Sutcliffe JL, Marik J, Pan C-X, Lam KS. From combinatorial chemistry to cancer-targeting peptides. Mol Pharm. 2007;4:631-651.

8. Ferrara N, Davis-Smyth T. The biology of vascular endothelial growth factor. Endocr Rev. 1997;18:4-25.

9. Park JE, Keller GA, Ferrara N. The vascular endothelial growth factor (VEGF) isoforms: differential deposition into the subepithelial extracellular matrix and bioactivity of extracellular matrix-bound VEGF. Mol Biol Cell. 1993;4:1317-1326.

10. Deshayes E, Dunet V, Rüegg C, Prior JO. Neoangiogenesis imaging in nuclear medicine. Médecine Nucléaire. 2012;36:619-626.

11. Fedorova A, Zobel K, Gill HS, et al. The development of peptide-based tools for the analysis of angiogenesis. Chem Biol. 2011;18:839-845.

12. Nagengast WB, de Vries EG, Hospers GA, et al. In vivo VEGF imaging with radiolabeled bevacizumab in a human ovarian tumor xenograft. $\mathrm{J}$ Nucl Med. 2007;48:1313-1319.

13. Chang AJ, Sohn R, Lu ZH, Arbeit JM, Lapi SE. Detection of rapalog-mediated therapeutic response in renal cancer xenografts using ${ }^{64} \mathrm{Cu}$-bevacizumab ImmunoPET. PLOS ONE. 2013;8:e58949.

14. Gaykema SB, Brouwers AH, Lub-de Hooge MN, et al. ${ }^{89} \mathrm{Zr}$-bevacizumab PET imaging in primary breast cancer. J Nucl Med. 2013;54:1014-1018.

15. Fairbrother WJ, Christinger HW, Cochran AG, et al. Novel peptides selected to bind vascular endothelial growth factor target the receptor-binding site. Biochemistry. 1998;37:17754-17764.

16. Pan B, Li B, Russell SJ, Tom JY, Cochran AG, Fairbrother WJ. Solution structure of a phage-derived peptide antagonist in complex with vascular endothelial growth factor. $J$ Mol Biol. 2002;316:769-787.

17. Marquez BV, Beck HE, Aweda TA, et al. Enhancing peptide ligand binding to vascular endothelial growth factor by covalent bond formation. Bioconjug Chem. 2012;23:1080-1089.

18. Prasanphanich AF, Nanda PK, Rold TL, et al. [ $\left.{ }^{64} \mathrm{Cu}-\mathrm{NOTA}-8-\mathrm{Aoc}-\mathrm{BBN}(7-14) \mathrm{NH} 2\right]$ targeting vector for positron-emission tomography imaging of gastrin-releasing peptide receptor-expressing tissues. Proc Natl Acad Sci USA. 2007;104:12462-12467.

19. Studer M, Meares CF. Synthesis of novel 1,4,7-triazacyclononane-N,N',N"'-triacetic acid derivatives suitable for protein labeling. Bioconjug Chem. 1992;3:337-341.

20. Kumar SR, Gallazzi FA, Ferdani R, Anderson CJ, Quinn TP, Deutscher SL. In vitro and in vivo evaluation of ${ }^{64} \mathrm{Cu}$-radiolabeled KCCYSL peptides for targeting epidermal growth factor receptor-2 in breast carcinomas. Cancer Biother Radiopharm. 2010;25:693-703.

21. Kume M, Carey PC, Gaehle G, et al. A semi-automated system for the routine production of copper-64. Appl Radiat Isot. 2012;70:1803-1806.

22. Stracher A, Becker RR. Polyvalyl-proteins. J Am Chem Soc. 1959;81:1432-1435.

23. Peterson KJ, Sadowsky JD, Scheef EA, et al. A fluorescence polarization assay for identifying ligands that bind to vascular endothelial growth factor. Anal Biochem. 2008;378:8-14.

24. Chakrabarti MC, Le N, Paik CH, De Graff WG, Carrasquillo JA. Prevention of radiolysis of monoclonal antibody during labeling. J Nucl Med. 1996;37:1384-1388.

25. Gerber H-P, Wu X, Yu L, et al. Mice expressing a humanized form of VEGF-A may provide insights into the safety and efficacy of anti-VEGF antibodies. Proc Natl Acad Sci USA. 2007;104:3478-3483.

26. Mei S, Cammalleri M, Azara D, Casini G, Bagnoli P, Dal Monte M. Mechanisms underlying somatostatin receptor 2 down-regulation of vascular endothelial growth factor expression in response to hypoxia in mouse retinal explants. J Pathol. 2012;226:519-533.

27. Kumar M, Liu Z, Thapa L, Chang Q, Wang D, Qin R. Antiangiogenic effect of somatostatin receptor subtype 2 on pancreatic cancer cell line: inhibition of vascular endothelial growth factor and matrix metalloproteinase-2 expression in vitro. World J Gastroenterol. 2004;10:393-399.

28. Tsuchihashi S-i, Ke B, Kaldas F, et al. Vascular endothelial growth factor antagonist modulates leukocyte trafficking and protects mouse livers against ischemia/reperfusion injury. Am J Pathol. 2006;168:695-705.

29. Kut C, Mac Gabhann F, Popel AS. Where is VEGF in the body? A meta-analysis of VEGF distribution in cancer. Br J Cancer. 2007;97:978-985.

30. Goldenberg DM, Rossi EA, Sharkey RM, McBride WJ, Chang C-H. Multifunctional antibodies by the dock-and-lock method for improved cancer imaging and therapy by pretargeting. J Nucl Med. 2008;49:158-163.

31. Wei LH, Olafsen T, Radu C, et al. Engineered antibody fragments with infinite affinity as reporter genes for PET imaging. J Nucl Med. 2008;49:1828-1835.

32. Aweda TA, Eskandari V, Kukis DL, et al. New covalent capture probes for imaging and therapy, based on a combination of binding affinity and disulfide bond formation. Bioconjug Chem. 2011;22:1479-1483. 